\title{
Starworld: Preparing Accountants For The Future: A Case-Based Approach To Teach International Financial Reporting Standards Using ERP Software
}

\author{
Joseph M. Ragan, Saint Joseph's University, USA \\ Christopher J. Savino, Saint Joseph's University, USA \\ Paul Parashac, Saint Joseph's University, USA \\ Jonathan C. Hosler, Saint Joseph's University, USA
}

\begin{abstract}
International Financial Reporting Standards now constitute an important part of educating young professional accountants. This paper looks at a case based process to teach International Financial Reporting Standards using integrated Enterprise Resource Planning software. The case contained within the paper can be used within a variety of courses to teach International Financial Reporting Standards within an ethical framework. This case does not require access to a live SAP ECC 6.0 server. Students desiring a real time technical experience can either use a live system or utilize the practice capability within this case. The product demonstrated uses the current version of SAP ECC 6.0.
\end{abstract}

Keywords: Enterprise Resource Planning, ERP education, IFRS education, SAP ECC 6.0 instruction, Teaching with Ethics

\section{INTRODUCTION}

n February of 2010 the SEC unanimously passed and outlined a new work plan that lays the groundwork C for a major vote that would decide if and when to transition to IFRS. Currently, the SEC envisions 2015 as the earliest possible date for required use of IFRS by all US public companies. For now, extensive study and research will be completed by 2011 to determine all possible consequences of this transition. Companies and organizations such as the AICPA welcome the work plan, they want to continue to move forward with the transition to IFRS (DeFelice).

As business schools attempt to globalize their accounting curriculum, they are presented with many opportunities and many challenges. A principal opportunity is offering a richer cultural curriculum for students exposing them to potential global research platforms enhanced by state of the art technology. The major challenge presented here is to implement this enhanced technology within a developing accounting curriculum.

In this paper we present the architecture and a detailed description of the process at Saint Joseph's University and the outcomes of integrating enterprise resource planning software and international financial reporting standards. These two educational objectives were satisfied with a grant-sponsored IFRS curriculum integration supported by PricewaterhouseCoopers. International financial reporting standards are likely to be mandated for US based publically held firms by January 1, 2015. The need exists to build educational material within our textbooks to enable this transition. Being IFRS-ready is a critical need for new entrants into the accounting profession. Our model for assuring that accounting graduates will be IFRS-ready is through integrative incorporation of international standards across the curriculum rather than delivery of a single, stand-alone course offering. The second objective stresses the professions strong inclination for inclusion of integrated business processes as a part of the student experience in the accounting program. In 2002, the Saint Joseph's University 
Accounting Learning framework and course design underwent a complete program reengineering to better link five courses that are the core accounting offerings for our major. The PwC grant-supported IFRS teaching package will have modules used in all five of these courses. This is a novel, a unique, and resource-efficient way to infuse IFRS during two or three years of our undergraduate students' studies. The simulation product, when fully developed, will have optional modules for use in other accounting courses. In addition, this inventive package will provide hands-on case-based ethical application using IFRS.

The core accounting curriculum — the focus for IFRS integration —is composed of the following courses:

Financial Accounting Information Systems I provides a conceptual basis and procedural framework for accounting. Here, students are introduced to business technology through the use of SAP ECC 6.0. The class strongly emphasizes knowledge of the accounting ledger and preparation of financial statements. (Equivalent to Intermediate I)

Financial Accounting Information Systems II coverage includes financial analysis and issues, of disclosure, display, and reporting. It stresses advanced conceptual topics, focusing particularly on the analysis of business problem situations. Technology is used to reinforce material learned; applications of the accounting recording/reporting model are placed in an ERP framework throughout the course. (Equivalent to Intermediate II)

Financial Accounting Information Systems III continues the systems orientation of the earlier two courses, adding topics such as business combinations, consolidation accounting, segment reporting, foreign operations, and global accounting reporting issues. There is advanced application use of SAP as students gain a greater appreciation of the enterprise-wide nature of this software product focus. (Equivalent to Advanced Accounting)

Management Accounting Information Systems I includes topics such as strategic cost management, reengineering, target costing, and managerial accounting for multinationals. Software applications, in an ERP framework, focus on responsibility accounting systems and management reporting. (Equivalent to Cost Accounting)

Management Accounting Information Systems II stresses internal and external reporting requirements, emphasizing specialized modules, such as customer relationship management, strategic enterprise management, balance scorecard and EVA analysis. All of which are placed within the enterprise resource planning structure supported by SAP. (Equivalent to Advanced Cost Accounting)

Our paper consists of a review of prior research as well as an overview of the course initiatives and learning outcomes of our development of the StarWorld practice set.

\section{BACKGROUND AND PRIOR RESEARCH}

Albrecht and Sack (2000) paint a dismal portrait of the academic accounting profession as a discipline stuck in the past and exhibiting an unwillingness to change. They observed that technological innovation has rendered the gathering and reporting of information as an inexpensive process in today's environment. Accountants must be armed, they proposed, with new skills if they are to find a role in today's environment. The pair suggested that accounting educators should embrace the unfolding internet revolution and include this experience as an integral part of the pedagogy of accounting education. There is an obvious need, in light of the scandals of 2001 to also provide ethics-based learning as well.

Accounting professionals recognize this revolutionary change, and promote the implementation of advanced technology for business processes. The AICPA (2000b) has made internet usage one of its top ten technologies for the start of the new century. When professionals were asked what skill other than financial expertise was most critical for success in the accounting discipline, the overwhelming choice was internet technology (AICPA, 2000a). Educational organizations, such as the Federation of Schools of Accountancy (1999), have offered strong recommendations for specific actions that might be taken by today's universities in an effort to improve technology education. Greater reliance on the internet is one of the cornerstones of such proposals (DePalma, 2004). 
Prior research has shown that the convergence of US and international financial standards is imminent. However, to best facilitate this convergence; it needs to start with education. The education of current professionals is certainly important, but in order for the convergence and the adoption of IFRS to truly take root, it needs to be taught in the colleges and universities across the country (Thomas, 2009). The problem, however, arises from the gap between the educators and students in favor of IFRS education and the wealth of international accounting information that is available. Bridging this gap can be best accomplished through the writing and publishing of more effective textbook material and the use of better educational materials and tools, along with a renewed focus on the importance of business ethics (Aisbitt, 2005; Brady and Larson, 2009).

There seems to be little disagreement that international accounting needs to be taught, but the issue is of how exactly IFRS should be taught in the classroom. International accounting is most effectively taught through case studies and real-life situations. Also, it is encouraged that professors should challenge their students through group cases and projects, therefore allowing the students to challenge each other as well (Karr, 2008). Studies show that this is also the best way to incorporate ethics as students can discuss within their group why might some decisions be more ethically sound than others (Quinn, 2005).

The goal of accounting education, among other things, is to prepare graduates for their careers in the professional accounting world. Schools are always looking for new ways to make the transition as smooth and as effective as possible from school to business. One way is to use ERP systems in education to study and work with certain industries to help close the gap between the skills of recent graduates and the skills demanded by the global business world today and into the future (Hawking and McCarthy, 2000). What makes ERP systems so special and so important in accounting education? ERP systems which are used extensively by the largest global firms capture the essence of business processes like nothing else can. In addition, these systems allow students to learn and apply international accounting. ERP systems allow for the following issues to be addressed: international aspects, collaborative business processes and the exploration of Business to Business (B2B) environments (Antonucci and Muehlen, 2000; Antonucci, 2000).

When incorporating ERP into education, it is more important to focus on how to implement the systems within the curriculum. To achieve the greatest benefit of a curricular ERP implementation, it must be present in more than just one course, so students would use ERP systems in several different courses, allowing them to apply various accounting aspects within one ERP system (Guthrie and Guthrie, 2000).

Surveys show that students are more willing to work with this software than are the educators. For an ERP implementation to be successful, educators must be ones who step up and take the lead in supporting and teaching with ERP systems (Becerra-Fernandez, Murphy, and Simon, 2000).

\section{PURPOSE}

The primary goal of our research is to show how a case-based approach to teaching International Financial Reporting Standards can be used in conjunction with Enterprise Resource Planning software. We are currently using ERP software and case-based questions to teach US GAAP accounting with much success. Given our extensive research, we were able to create practice sets and cased-based questions focused on international accounting concepts and ethical issues. Following the development of these practice sets, we proceeded to test them for their feasibility and effectiveness. This testing allowed us to further improve the practice sets and work to build one major case-based practice set than can be used in several courses to teach numerous accounting issues especially those dealing with International Financial Reporting Standards. This case-based problem is the case that is featured within this paper. Our focus is to integrate International Financial Reporting Standards with Enterprise Resource Planning software, such as SAP, and a case-based ethics practice set.

\section{SAP UNIVERSITY ALLIANCE}

Although a live connection to SAP ECC 6.0 software is not required, it is highly recommended. Our access to SAP was made possible for us through the SAP University Alliance program. The SAP University Alliance program is a global endeavor that provides university faculty members with the tools and resources necessary to 
teach students how technology can enable integrated business processes and strategic thinking - and gives students the skills to add immediate value to the marketplace. SAP University Alliance member schools gain access to the SAP Business Suite family of solutions, including SAP ERP. This comprehensive business software suite supports business, engineering, and information technology programs, enabling students to put classroom theory into practice through demonstrations, exercises and problem-solving, case studies, and research programs.

The use of this case in the classroom will greatly help in the education of three very important topics in accounting education today. They are international accounting, the use of ERP software such as SAP, and the understanding of ethical business processes.

International accounting is taught through the emphasis of key differences between US GAAP and IFRS. When teaching to students who are familiar with US GAAP, it is important to note that the majority of accounting they originally learned is staying the same. Comparing and contrasting the two sets of standards shows the different methodology between them. Being that IFRS is more principle-based, it is important to educate the students on some of those guiding principles. Once a general understanding of IFRS is taught, the key differences between US GAAP and IFRS are taught through conversion and reconciliation practice sets, where students will have to calculate balances under both US GAAP or IFRS and then make the adjusting entries to reconcile the accounts to the other standards. In addition to learning the principles of IFRS and the application of those principles, students will learn the effect that going from US GAAP to IFRS and vice versa. The benefit of seeing both systems lies in the fact that US GAAP is unlikely to go away and will most likely be used by companies that are not publically traded and firms that are not for profits. The initial edition of StarWorld allows students to examine the major differences between the two set of standards. Subsequent editions could eliminate the US GAAP applications.

The use of ERP software is vital in this case and in accounting education in general. The type of ERP software we used in this case is SAP ECC 6.0. ERP software is taught by allowing each of the students to log into an ERP system and perform a number of transactions within different business cycles. Today, ERP technology is used in one form or another by nearly all successful business both big and small. Developing a comfort level with this technology is just one of the goals of using this software in the classroom. The main goal is to show the students how ERP systems can better integrate business processes along with the flow of financial information throughout the many business cycles of a company. Additionally, the ERP software will track this flow of financial information and therefore allow the students to analyze those financials in order to make decisions on the balances and trends of the company.

This is all accomplished by our featured case study called StarWorld. StarWorld is then further broken down into five modules and each module focuses on a different aspect of accounting. StarWorld assigns each student an individual company code so that all their transactions are be recorded in their own general ledger. Module I will cover basic transactions by having the students read a scenario and record transactions as they are described in the scenario. Following this, students will then enter the transactions into SAP. The ethical framework of reporting, as published by the AICPA, is reviewed with the students at this point. Module II will cover the purchasing cycle by using the purchase order along with required master files within SAP. Ethical issues and internal controls inherent in purchasing are then reviewed. Module III will deal with the sales cycle by working with the sales order and the other requisite master files within SAP associated with the sales cycle. Ethical issues and internal controls inherent in sales are then reviewed. Module IV will allow the students to utilize the reporting capabilities of SAP by looking at their company code's financial statements after the completion of Modules I through III. The financial statements compiled by SAP can then be exported to Excel for further analysis. Finally, Module V will then focus on the impact of switching to International Financial Reporting Standards from US GAAP. SAP's ability to communicate with and process several different accounting standards makes SAP incredibly useful for teaching the impact of IFRS along with the necessary reconciliations of conversion. A special focus here will be on the ethical framework established within International Financial Reporting Standards. This will include a discussion of principles-based versus rules-based accounting, as well as inherent issues of transparency in international reporting. 


\section{STAR SCHOLARS}

A unique feature of the course pedagogy is the utilization of STAR Scholars to assist in the development and delivery of various SAP scenarios. These scholars are chosen through a highly selective process and are specially trained to deal with these application scenarios. To date, there are some sixteen STAR Scholars comprised mostly of juniors and senior undergraduate majors. These students are compensated for the work done in class and are provided with enrichment activities, such as field visits and special speakers, helping them to understand the essentiality of the implementation of state of the art software. They often participate in research-based projects designed and developed by faculty. In addition, STAR Scholars involve themselves in a series of special activities under the direction of a Faculty mentor. Developing scenarios of various computer applications involving Enterprise Resource Planning software and SAP are included. In addition, seminars with entrepreneurs and technology leaders to provide opportunities to interact on a personal and informal level are held with business leaders. Sponsored participation in special events with alumni working in technology and consulting fields is also a component. These students assist in classroom delivery and continue to service the course by maintaining a helpdesk for students.

\section{PRACTICE CASE}

The practice set that we used was developed at Cal State Chico by Dr. James Mensching. Dr. Mensching is a leading developer in accounting information systems material. This material is readily transferable to the classroom and is an excellent platform from which to use SAP ECC 6.0.

\section{MODULE I - LEDGER PHASE}

Scenarios are written in the form of scripts and tested by the STAR Scholars prior to their use in class. Students follow the script to complete the process. A good way to create interest for the students is to use the email function within the SAP system. This is done by emailing a question from our hypothetical employee, such as a $\mathrm{CEO}, \mathrm{CFO}$, etc., asking a question pertaining to the scenario to be performed in class. After the scenario is performed the students respond to the question which forces them to explain the task they performed and how it affected the business. Each student's response will contain an attached report, which will give the instructor enough information to give the student credit for the assignment. This also allows observations of ethical applications and reasoning within the email.

It is essential for students to understand the relationship between the concept coverage within the text and the applications within SAP. A very simple overview of SAP navigation is completed in this process. The students leave with a scavenger hunt assignment using SAP navigation. Students are also introduced to the faculty website and the blackboard location for course documents and assignments. Using SAP ECC 6.0, students can now begin a walkthrough of the topics in the first accounting course. These topics primarily include financial statement reporting and assets. As each topic is reviewed, assignments are handed out for completion by the students, and subsequently graded upon the students' submission.

\section{MODULE II - PURCHASING}

In this module, students will follow the script to complete a simulation of the purchasing cycle, which begins with the creation of a purchase requisition to permit the procuring of the materials. The purchase requisition aids in the creation of a formal purchase order. Once completed, the system will send the purchase order to the vendor triggering the vendor's system to send the desired materials back to the student's company. Students will then create a goods receipt to verify the delivery of the materials. In addition to the materials, an invoice is sent and must be paid by the student for the purchase. Once the invoice is completed and cash is paid, the purchasing cycle is complete. Students will be able to verify the above cycle by periodically checking the ledgers of inventory and cash to observe how each account changes throughout the process. 


\section{MODULE III - SALES}

After completion of Module II, students will now have inventory that they are able to sell. Module III is a simulation of the sales cycle. Students will complete this the same way as the previous modules by following a script. The process will begin by the student receiving and recording a sales order inquiry, recording information about the potential customer, such as name, address and desired product and quantity. From the inquiry, students will then create a formal sales order. Following completion of the sales order, students must prepare the materials for shipping and then finally ship the goods. This is done by completing a transfer order and a picking document for the goods, which will trigger the employees of the warehouse to release the goods, prepare them, and deliver them to the shipping point. At this time, the student will make the transaction by posting the goods issued. Immediately, the student will create an invoice to be sent to the customer for the order, thus creating a receivable for the company. To complete the sales cycle, the student will collect cash from the customer and ultimately confirm the sales order process. To review the process, students will then view a copy of the document flow showing the flow from sales inquiry to sales order all the way down to invoice and collection of cash and the status of each step, either open and not completed or cleared and completed.

\section{MODULE IV - FINANCIAL STATEMENT ANALYSIS}

In this module, students will view the updated financial statements reflecting the recent activity and current financial position of the student's company in the system. There are in fact two separate companies. The 8000 ledger (called company code within SAP) deals with US GAAP. In addition, the students have prepared the same entries in the 9000 ledger, which is in fact done according to International Financial Reporting Standards. Each ledger will produce its own set of statements. Upon viewing the statements in the system, SAP allows the students to export the financials to a spreadsheet such as Microsoft Excel. Once in Excel, the students are able to perform certain analytical procedures on the statements such as vertical and horizontal analysis. In addition, the students will be asked to compute various financial ratios and make conclusions on the company based on those ratios and analysis. They quickly determine that different methods of GAAP produce interesting results. These observations become the basis for further classroom discussion.

\section{MODULE V - CONVERSION TO IFRS}

This is the summary module in that it brings all of the material together. From an Excel spreadsheet, which they downloaded from SAP ECC 6.0, the students will do a series of adjustments to bring the U.S. GAAP financial statements to International Financial Reporting Standards. The paper reflects only five of the most significant ethical issues around which accountants must intervene in financial reporting. The students are asked to analyze the finance ratios again identified in Module IV to see the effects on going from U.S. GAAP to International GAAP (iGAAP). Through discussion, students are asked to identify key ethical issues that would also be apparent in the financial conversions. Moving from rules based to principles based is always a highlight of discussion. In addition, students like to talk about financial transparency and the need for preventive controls to enable fairness in financial reporting.

\section{COMPETENCY OUTCOMES}

The rubric below is used to assign a grade for the judgments made by students as they tackle various aspects of this case.

In addition to this rubric, each module is submitted for grading and assessment within the SAP Business Workplace. Business Workplace provides an email system where students can submit their analysis and any Excel / Word attachments. A survey was provided to students during the last week of class. Appendix B provides a summary of survey results. It is interesting to note that some $94 \%$ of the students agree or strongly agree that the StarWorld case supplemented their understanding of systems concepts in Management Accounting Information Systems (chart 2). A similar number believe it should be continued to be used (chart 6). Some 96\% agree or strongly agree that the amount of work done on the case material was justified based on the learning derived. This is based on responses by 50 out of 88 students $(56.8 \%)$ in the class participating in this project. 


\begin{tabular}{|c|c|c|}
\hline Competency Description & $\begin{array}{c}\text { Strategy } \\
\end{array}$ & $\begin{array}{r}\text { Assessment Methods } \\
\end{array}$ \\
\hline $\begin{array}{l}\text { The student will be able to: } \\
\text { 1. list the ethical issues associated with } \\
\text { the use of computer technology in our } \\
\text { global society and identify possible } \\
\text { solutions to these problems given your } \\
\text { knowledge of the financial accounting } \\
\text { ledger } \\
\text { 2. identify the factors affecting security } \\
\text { in information systems and the } \\
\text { techniques involved in disaster planning } \\
\text { and recovery; prepare business process } \\
\text { blueprint for purchasing } \\
\text { 3. identify the financial accounting and } \\
\text { control issues associated with sales order } \\
\text { systems; prepare business process } \\
\text { blueprint for sales } \\
\text { 4. identify and discuss issues in financial } \\
\text { reporting and analysis and determine } \\
\text { what the ratios are really trying to tell us; } \\
\text { Is U.S. GAAP really good GAAP? } \\
\text { 5. identify the major differences between } \\
\text { U.S. GAAP and iGAAP and show their } \\
\text { effects on financial statements }\end{array}$ & $\begin{array}{l}\text { Together, the students and the } \\
\text { professor will: } \\
\text { 1. examine the problems associated } \\
\text { with advanced in computer } \\
\text { technology and discuss, in detail, } \\
\text { possible solutions to these } \\
\text { problems; gain awareness of } \\
\text { financial ledger within ERP systems } \\
\text { 2. use critical thinking skills to } \\
\text { debate their various points of view } \\
\text { regarding each control issue covered } \\
\text { in this unit; become aware of the } \\
\text { purchasing process within SAP } \\
\text { ECC 6.0 } \\
\text { 3. investigate the moral, legal and } \\
\text { ethical applications of SAP } \\
\text { technology within the sales and } \\
\text { distribution process } \\
\text { 4. listen to guest speakers discuss } \\
\text { their points of view related to the } \\
\text { framework of U.S. GAAP; Does } \\
\text { that framework really provide } \\
\text { transparency? Does it provide } \\
\text { fairness? } \\
\text { 5. conduct independent research on } \\
\text { the evolving International Financial } \\
\text { Reporting Standards }\end{array}$ & $\begin{array}{l}\text { The student will: } \\
\text { 1. answer questions regarding the } \\
\text { professional, moral, legal, and ethical uses of } \\
\text { computers and information technology; } \\
\text { complete at least sixty transactions within an } \\
\text { SAP ECC } 6.0 \text { ledger and evaluate fairness of } \\
\text { reporting } \\
\text { 2. prepare succinct written analyses using } \\
\text { SAP Business Workplace (email) of critical } \\
\text { issues related to the control challenges of } \\
\text { computer technology; develop master file } \\
\text { structure and complete a series of purchasing } \\
\text { transactions } \\
\text { 3. prepare succinct written analyses using } \\
\text { SAP Business Workplace of critical issues } \\
\text { related to the control challenges of computer } \\
\text { technology; develop master file structure and } \\
\text { complete a series of sales transactions } \\
\text { 4. complete financial statement analysis that } \\
\text { evaluates the impact transactions have had on } \\
\text { the financial reports; prepare a succinct } \\
\text { written analysis using SAP Business } \\
\text { Workplace which evaluates the performance } \\
\text { of the simulation company } \\
\text { 5. prepare a comparative analysis of the } \\
\text { effects on ratios of going from U.S. GAAP to } \\
\text { iGAAP; prepare a succinct analysis using } \\
\text { SAP Business Workplace discussing ethical } \\
\text { issues of using a principles based approached } \\
\text { to financial reporting }\end{array}$ \\
\hline
\end{tabular}

\section{SUMMARY AND CONCLUSION}

In this paper, we describe and examine a unique approach to teaching international accounting standards and ethics through enterprise process integration and reporting. Benefits derive from the fact that students have multiple exposures to a single company, allowing them to become familiar with its products, manufacturing processes and its industry. Each student has the opportunity to examine the company at different functional perspectives while remaining cognizant of the corporation as a whole. This cross-functional approach provides insight into other disciplines, allowing students to gain a real appreciation of business decision-making using integrative technology and learning the functionality of SAP ECC 6.0.

This project was tested within a group of typical, accounting information systems courses offered at an American university. The simulation involved rolling out enterprise resource planning within these classes to see what impact it would have on the learning efficacy of the students. Students were graded on project completion and a follow-up survey was conducted to determine assessment of learning and attitudes developed by students about the case, technology and material (see Appendix B). Saint Joseph's University requires all students to have laptops. A typical class consists of 30 students and is taught over a fourteen week semester.

A major objective of the project was to provide an integrative experience in which students gained a better understanding of core business processes and the ethical applications within them. Overall, this objective appeared to be achieved at a satisfactory level as evidenced by the survey results found in Appendix B. The reporting activity (see Appendix A) forced students to look at dollar impact and financial results of transitioning from U.S. GAAP to iGAAP. Students saw the ratios improving given the adjusting entries provided in the case situation. They also found that changing accounting framework also changed the ethical context in which decisions were made. While all the students appeared to grasp the integrative elements of the ERP System, not all students felt the project taught 
them the necessary process steps to effectively navigate SAP on their own. Functional specialization (stove piping) did creep into team activities. Team members were allowed to focus too narrowly on their own functional departments and tended not to become very proficient with the parts of the ERP System that lay outside their boundaries. We plan to pursue this issue in subsequent academic papers.

\section{AUTHOR INFORMATION}

Joseph M. Ragan is Professor and Chair for the Department of Accounting at St. Joseph's University. He is the author of several books and articles dealing with the implementation of SAP solutions within business systems. He is also the founder of the Philadelphia Consulting Group and has served as a Systems Consultant to Fortune 500 companies. $\mathrm{He}$ is an educational thought leader for SAP America and currently teaches in the accounting information systems field.

Christopher J. Savino, Chris is a recently graduated accounting and finance major from Saint Joseph's University. He has been working with SAP as a STAR Scholar at Saint Joseph's University since 2008. Chris is a SAP Certified Solutions Consultant. Following both his sophomore and junior years, he interned with PricewaterhouseCoopers, in Jersey City, NJ and Philadelphia, PA, respectively. Chris will be starting his career as a Systems \& Process Assurance Associate for PricewaterhouseCoopers in Philadelphia, PA.

Paul Parashac, Paul is a recently graduated accounting major from Saint Joseph's University. He has been working with SAP as a STAR Scholar at Saint Joseph's University since 2008. Following his junior year, Paul interned with Deloitte \& Touche in Philadelphia, PA in their Audit practice. He will be starting his career as an Audit Associate for Deloitte \& Touche in Philadelphia, PA.

Jonathan C. Hosler, Jonathan is an accounting and business intelligence major at Saint Joseph's University. He has been working with SAP as a STAR Scholar since 2008. JC is a SAP certified solutions consultant. During his freshman year at Saint Joseph's University he was accepted as a STAR Scholar where his involvement with SAP began. In addition to his life as a student, Jonathan is a co-founder of Authentic Lacrosse, an online shopping store for lacrosse equipment.

\section{REFERENCES}

1. AICPA (2000a). “AICPA Core Competency Framework for Entry into the Accounting Profession," http://www.aicpa.org/edu/func.htm.

2. AICPA (2005). Accounting Education Change Commission. 1990. Objectives of Education for Accountants: Position Statement Number One. Issues in Accounting Education (Fall): pamphlet. Retrieved December 12, 2009, from http://www.nasba.org/nasbaweb/NASBAWeb.nsf/PS/95511CC8CE69334A862571B900755B3F/\$file/AIC PA\%20Framework.pdf

3. AICPA Top Ten Technologies Task Force (2000b). “The AICPA Top Ten Technologies for 2000," http://www.toptentechs.com.

4. Aisbitt, Sally. "International Accounting Books: Publisher's Dream, Author's Nightmare and Educators' Reality." Accounting Education: an international journal 14.3 (2005): 349-360. Print.

5. Albrecht, W. Steve and Robert J. Sack. Accounting Education: Charting the Course Through a Perilous Future. Sarasota, FL: American Accounting Association, 2000.

6. Antonucci, Y. and M. Muehlen (2000), "Developing an International Business to Business Process Curriculum: Extending the Classroom Walls with ERP-Software.” Proceedings of ISECON 2000, Vol. 17 (Philadelphia), No. 121, AITP Foundation for Information Technology Education.

7. Becerra-Fernandez, I., K. Murphy, and S. Simon (2000), "Integrating ERP in the Business School Curriculum.: Communications of the ACM", Vol. 43, No. 4, pp. 39-41.

8. Brady, Thomas J., and Larson, Robert K. (2009), "Incorporating IFRS into the Accounting Curriculum," Strategic Finance, Vol. 90, No. 8, pp. 23-25.

9. DeFelice, Alexandra, and Lamoreaux, Matthew G. Lamoreaux (2010), “The SEC's IFRS Work Plan," Journal of Accountancy 
10. DePalma, Paul, ed. (2004) Computers in Society 05/06, $12^{\text {th }}$ ed. New York: McGraw Hill / Dushkin.

11. Federation of Schools of Accountancy (1999). "Recommendations for the Design of Empirical Studies Examining Curricular Efforts to Develop Student Critical Thinking Skills," http://www.thefsa.org/publications/studies.htm.

12. Ferrell, O. C. and G. Hirt (2003), Business: A Changing World, Fourth Edition, McGraw-Hill Irwin, Boston.

13. Guthrie, R. and R. Guthrie (2000), "Integration of Enterprise System Software in the Undergraduate Curriculum.” Proceedings of ISECON 2000, Vol. 17 (Philadelphia) No. 301., AITP Foundation for Information Technology Education.

14. Hawking, P. and B. McCarthy (2000), "Industry Collaboration: A Practical Approach for ERP Education." Proceedings of the Australasion Conference on Computing Education, pp. 129-133.

15. Joseph, G. and A. George (2002), "ERP, Learning Communities, and Curriculum Integration." Journal of Information Systems Education, Vol. 13, No. 1, pp.51-58.

16. Karr, Susan Schott. "Climbing the Learning Curve from GAAP to IFRS." Financial Executive 24.5 (2008): 46-49. Print.

17. Kroll, Karen (2009), “Is it U.S. GAAP or IFRS at U.S., Universities?” Financial Executive, Vol. 25, No. 5, p. 52-55.

18. Madison, R.L. \& Schmidt, J. (2006). Survey of time devoted to ethics in accountancy programs in North American colleges and universities. Issues in Accounting Education, 21, p.99-109

19. Monger, Rod. Financial Accounting: A Global Approach. N.p.: John Wiley \& Sons, Ltd., 2009. Print.

20. Morgan, John (2009), "World Awaits U.S. Action on Accounting Standards." Money Management Executive, Vol. 17, No. 37, p. 1-9.

21. Nilsen, Kim (2008), "On the Verge of an Academic Revolution.” Journal of Accountancy, Vol. 206, No. 6, p. 82-85.

22. "Professors urge IFRS education" (2009), Accounting Today, Vol. 23, No. 16, pp. 9-9.

23. Quinn, Michael J. (2005) Ethics for the Information Age, New York: Addison-Wesley.

24. Sunder, Shyam (2009), "IFRS and the Accounting Consensus." Accounting Horizons, Vol. 23, No. 1, p. 101-111.

25. Thomas, James. "Convergence: Businesses and Business Schools Prepare for IFRS." Issues in Accounting Education 24.3 (2009): 369-376. Print. 
APPENDIX A - FINANCIAL STATEMENTS AND RATIOS

\section{INCOME STATEMENT}

Sales

Resale Merchandise Sales

Event Merchandise Sales

Gross Sales

Less: Cash Discount

Net Sales

Cost of Goods Sold - Resale Merchandise

Cost of Goods Sold - Event Merchandise

Total: Cost of Goods Sold

Gross Profit

Expenses

Advertising Expenses

Depreciation and Amortization Expense

Insurance Expense

Interest Expense

Office Supplies Expense

Litigation Expense

Salaries/Wages Expense

Shipping Expenses

Utilities Expense

Bad Debt Expense

Total Operating Expenses

Operating Income

Other Revenue

Net Income Before Tax

Tax Expense

Net Income After Tax, Before Extraordinary Items

Extraordinary Gain - Condemnation Settlement (40,000 less tax of 6,400)

Net Income After Tax \& Extraordinary Items
GAAP

2010

171,340

168,760

340,100

1,000

339,100

105,144

105,262

210,406

128,694

600

900

400

705

514

5,000

42,600

2,899

2,663

1,297

57,578

71,116

-

71,116

12,000

59,116

33,600

92,716

290,200

92,716

382,916
IFRS

2010

171,340

168,760

340,100

1,000

339,100

83,394

21,750

83,162

166,556

172,544

600

2,300

400

705

514

7,500

42,600

2,899

2,663

1,297

61,478

111,066

40,000

(E)

151,066

18,400

132,666

(E)

33,600

132,666

(E)

(D)

290,200

111,066

401,266

Adjustment References:

A) Adjustment from LIFO Inventory Valuation to FIFO Inventory Valuation (IAS 2)

B) Fixed assets adjusted to benchmark treatment (IAS 16)

C) Intangible assets - adjustment for development (IAS 38)

D) Loss contingencies - adjustment for estimate (IAS 37) Range of loss 80,000 to 100,000

E) Extraordinary gain - Condemnation Settlement (IAS 1) 


\begin{tabular}{|c|c|c|c|c|c|}
\hline BALANCE SHEET & $\begin{array}{l}\text { US GAAP } \\
2010\end{array}$ & $\begin{array}{l}\text { Adjustments: } \\
\text { Debit }\end{array}$ & Credit & $\begin{array}{l}\text { IFRS } \\
2010\end{array}$ & \\
\hline \multicolumn{6}{|l|}{ Current Assets } \\
\hline Cash (Bank of America checking account) & 161,954 & & & 161,954 & \\
\hline Allowance for doubtful accounts & $(3,118)$ & & & $(3,118)$ & \\
\hline Resale Merchandise Inventory & 162,677 & 21,750 & & 184,427 & (A) \\
\hline Event Merchandise Inventory & 144,860 & 22,100 & & 166,960 & (A) \\
\hline Office Supplies & 450 & & & 450 & \\
\hline Prepaid Insurance & 4,400 & & & 4,400 & \\
\hline Prepaid Rent & 5,000 & & & 5,000 & \\
\hline Prepaid Advertising & 12,600 & & & 12,600 & \\
\hline Deferred Tax & 21,600 & & & - & \\
\hline Total Current Assets & 510,423 & & & 532,673 & \\
\hline \multicolumn{6}{|l|}{ Property Plant and Equipment } \\
\hline Warehouse and Office Equipment & 189,260 & 10,000 & & $199,260.00$ & (B) \\
\hline Accumulated Depreciation - Equipment & 22,500 & & & 22,500 & \\
\hline Net Property Plant and Equipment & 166,760 & & & & \\
\hline \multicolumn{6}{|l|}{ Intangibles } \\
\hline Brand Value & & 14,000 & 1,400 & 12,600 & $(\mathrm{C} 1, \mathrm{C} 2)$ \\
\hline Total Assets & 677,183 & & & 722,033 & \\
\hline \multicolumn{6}{|l|}{ Liabilities \& Shareholders' Equity } \\
\hline Current Liabilities & & & & & \\
\hline Accrued Wages Payable & 21,600 & & & 21,600 & \\
\hline Accrued Sales Tax Payable & 348 & & & 348 & \\
\hline Current Maturities of Long-Term Debt & 11,308 & & & 11,308 & \\
\hline Other Accrual for Litigation & 2,663 & & 2,500 & 5,163 & (D) \\
\hline Total Current Liabilities & 35,919 & & & 38,419 & \\
\hline \multicolumn{6}{|l|}{ Long Term Liabilities } \\
\hline Notes Payables & 58,348 & & & 58,348 & \\
\hline Total Long Term Liabilities & 58,348 & & & 58,348 & \\
\hline \multicolumn{6}{|l|}{ Shareholders' Equity } \\
\hline Common Stock - (no par) & 200,000 & & & 200,000 & \\
\hline Retained Earnings & 382,916 & & & 401,266 & \\
\hline Other Comprehensive Income (revaluation of bldg.) & & & 10,000 & 10,000 & (B) \\
\hline Brand value capitalized & & & 14,000 & 14,000 & (C1) \\
\hline Total Shareholders' Equity & 582,916 & & & 625,266 & \\
\hline Total Liabilities \& Stockholders' Equity & 677,183 & & & 722,033 & \\
\hline Weighted Average Shares O/S & 25,000 & & & 25,000 & \\
\hline
\end{tabular}

Adjustment References:

A) Adjustment from LIFO Inventory Valuation to FIFO Inventory Valuation (IAS 2)

B) Fixed assets adjusted to benchmark treatment (IAS 16)

C) Intangible assets - adjustment for development (IAS 38)

D) Loss contingencies - adjustment for estimate (IAS 37) Range of loss 80,000 to 100,000

E) Extraordinary gain - Condemnation Settlement (IAS 1)

\begin{tabular}{lll|}
\hline \multicolumn{1}{l}{ SELECTED FINANCIAL RATIOS } & \\
& GAAP & IFRS \\
Current Ratio & 14.21 & 13.86 \\
Quick Ratio & 5.65 & 4.72 \\
Gross Profit Margin & $37.84 \%$ & $50.73 \%$ \\
BV per Share & $\$ 23.32$ & $\$ 25.01$ \\
EPS, Basic & $\$ 3.71$ & $\$ 5.31$ \\
Return on Common Equity & $8.16 \%$ & $21.76 \%$ \\
Return on Assets & $14.04 \%$ & $18.85 \%$ \\
Total Asset Turnover & $0.52 \mathrm{x}$ & $0.48 \mathrm{x}$ \\
Inventory Turnover & $0.70 \mathrm{x}$ & $0.49 \mathrm{x}$ \\
& & \\
SELECTED FINANCIALS & & \\
Stockholders' Equity & 553,770 & 594,003 \\
Total Assets & 643,324 & 685,931 \\
Total Inventory & 292,160 & 333,818 \\
\hline
\end{tabular}




\section{APPENDIX B - STARWORLD SURVEY REPORT}

Unless noted, results refer to the number of students. 50 out of 88 students $(56.8 \%)$ in the class participated in this survey.

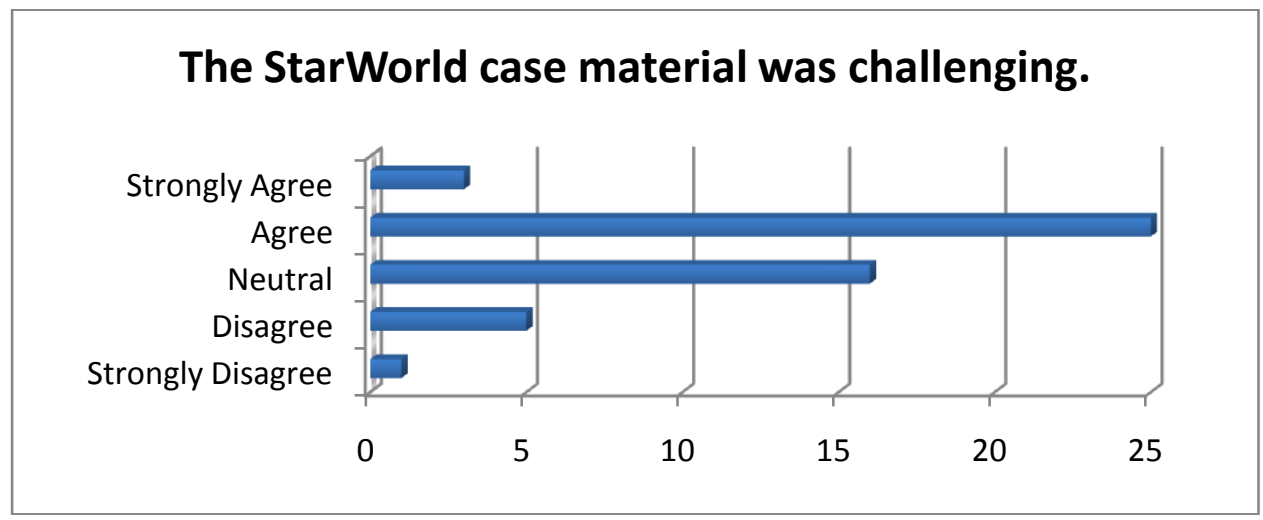

Chart 1.

The use of this case material supplemented my understanding of enterprise system concepts and managerial accounting systems.

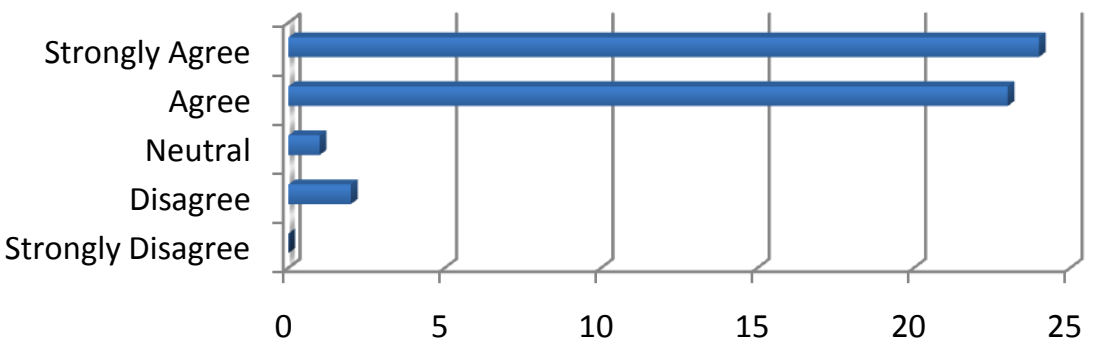

Chart 2.

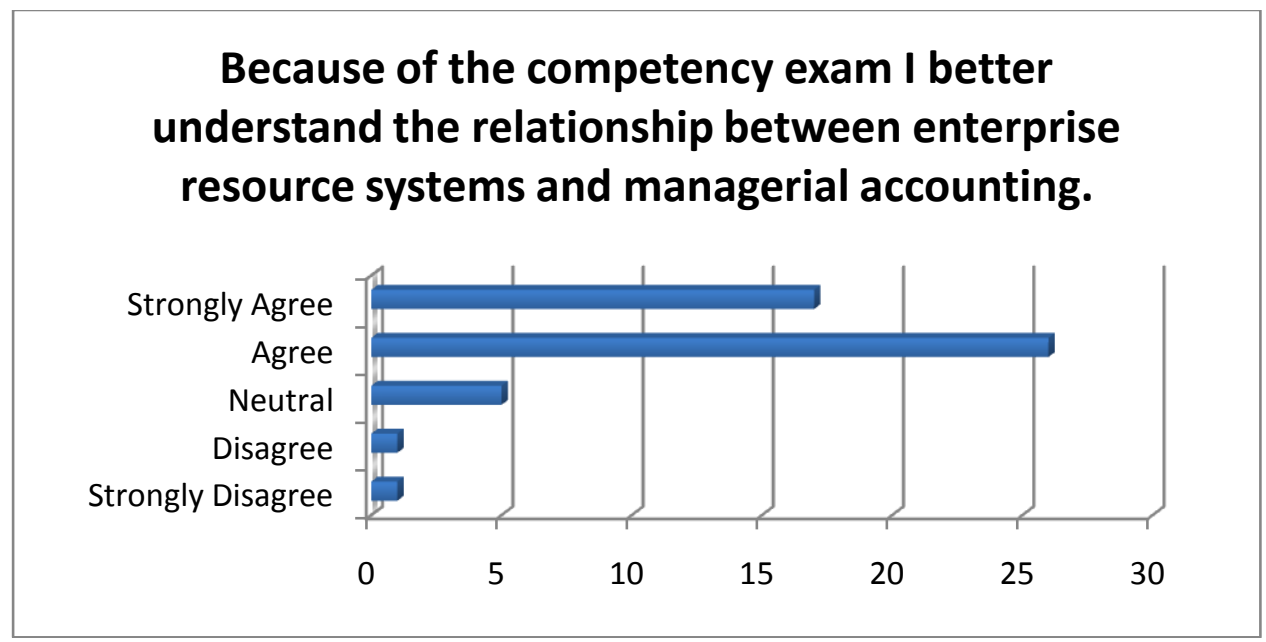

Chart 3. 
The case material increased my knowledge related to the enterprise systems terms and definitions.

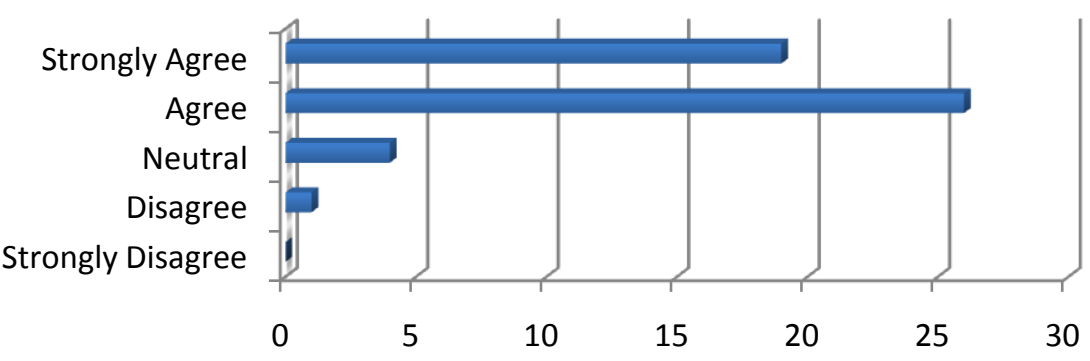

Chart 4.

The SAP homework assignments helped me to make evaluations and judgements about business process functions and activities.

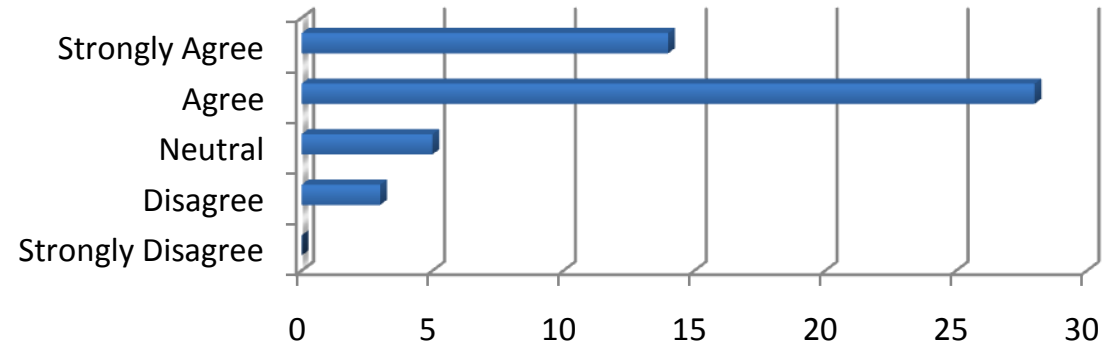

Chart 5.

Overall, I think the StarWorld case study is a useful project and should be continued in the Managerial Accounting Information Systems Class.

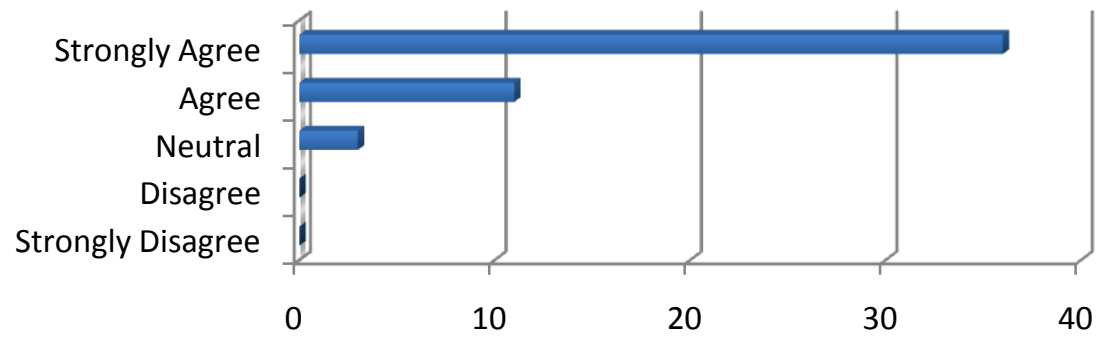

Chart 6. 


\section{The amount of work done on the case material} was justified based on the learning derived.

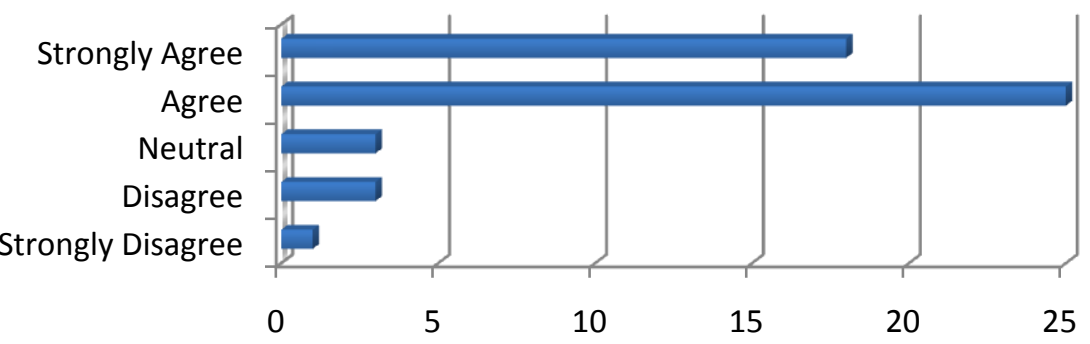

Chart 7.

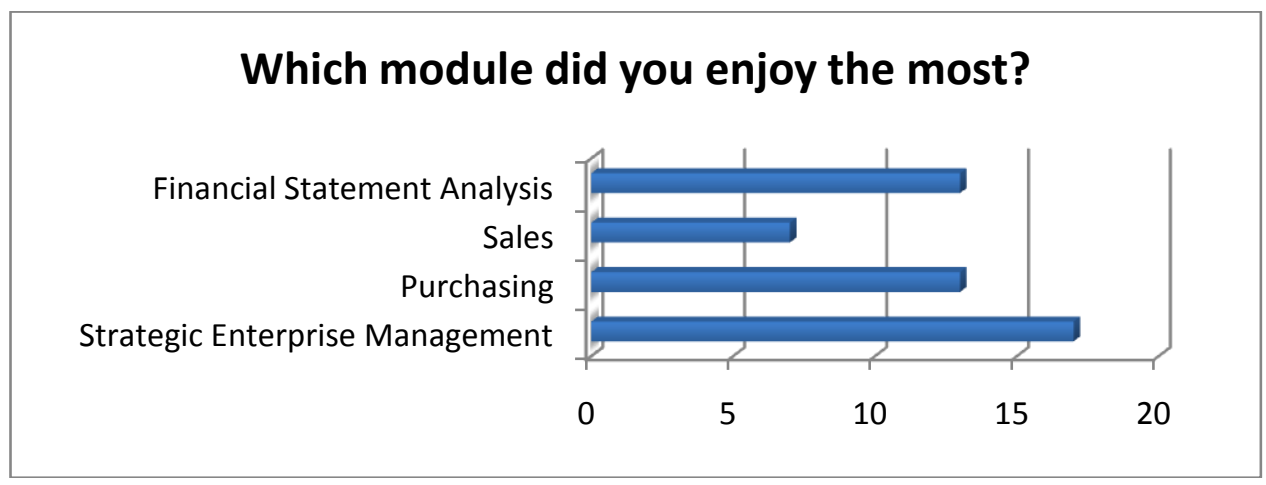

Chart 8.

Which module did you enjoy the least?

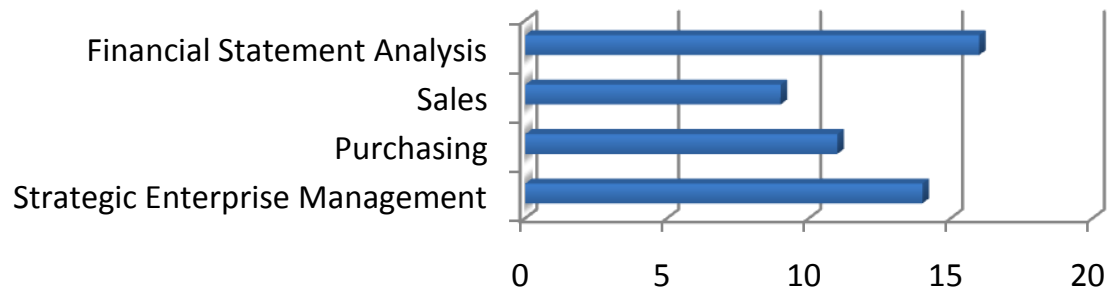

Chart 9. 


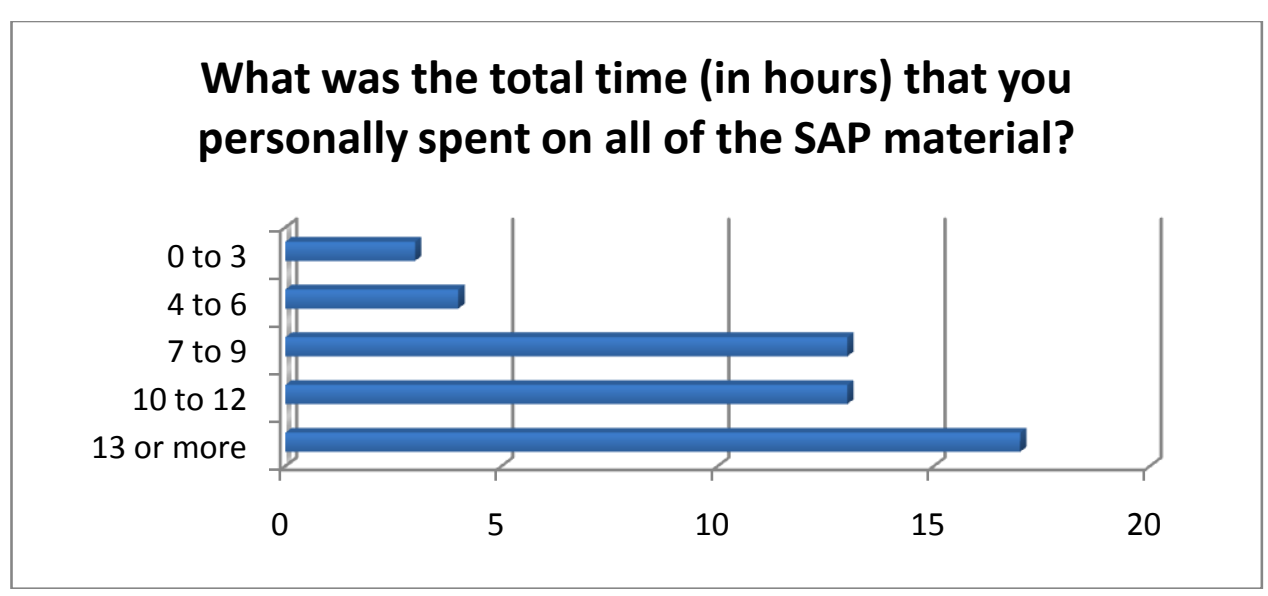

Chart 10.

Are there any additional comments you would like to submit that this survey did not cover?

"I thought Strategic Enterprise Management and the data warehouse, was by far the most interesting out of the group. I really thought it was most useful because we weren't just going through and clicking what the packet says to. In module 5, we were told what to go into, and from there we were able to be creative and give our input on how the company looks from our perspective."

“The supplemental videos are very helpful because I was not experienced with the business warehouse."

"It was helpful in not only performing the motions, but understanding the reasoning behind them."

"Keep the SAP program around; it is interesting and it is nice to not always have homework that is textbook problems."

"I think the SAP is one of the best things to happen to the Accounting Program at Saint Joseph's University. Not many students can leave college with a comprehensive overview of such difficult and important R/3 accounting software."

"I think that the SAP program was essential to learning the material in a way that will be applicable in the real world. Also, I think it was important we used a hands-on approach to learning because it helped me to better understand the concepts and processes."

"The SAP material is by far the most interesting and as far as I know will be the most useful accounting material $i$ have studied so far here at school. I can only assume that it provides and incredible advantage when seeking a job after school. The STARS scholars and Prof. Ragan covered and explained the material extremely well, and were extremely patient with everyone. Overall, MAIS II is one of if not my favorite accounting courses."

"SAP was a very interesting program that I felt I took a lot of information from. Great part of the class."

"SAP was a real plus to the course"

Figure 1. 
NOTES 